\section{Influence of Seed: Water Ratio and Shredding Time on Dehulling Process of Pigeon Pea}

\section{Subuola B Fasoyiro ${ }^{1 *}$, Rebecca Hovingh ${ }^{2}$, Hassan G Gourama ${ }^{3}$ and Catherine N Cutter ${ }^{3}$}

${ }^{1}$ Institute of Agricultural Research and Training PMB 5029, Moor Plantation, Ibadan, Nigeria

${ }^{2}$ Department of Food Science, Penn State University, University Park, PA, 16802, USA

${ }^{3}$ Penn State Berks Campus, Readings, PA, 19610, USA

\begin{abstract}
Pigeon pea seeds were pre-treated by blanching and dehulled by shredding at different times and varying seed to water ratio (seed: water), using a simple blender. Shredded fractions were weighed and used to calculate dehulling yields, as well as evaluated visually for brokenness of shells. Yields of total dehulled pigeon pea samples at $1: 1$ and 1:1.5 seed: water (111.72-154.68 g) doubled that which were obtained at 2:1 seed: water (53.69-60.49 g). Negative dehulling indices of -0.35 to -0.18 were obtained for pigeon pea samples PP1, PP2, and PP3 with seed: water of 2:1 and shredded for 10, 20 and $30 \mathrm{sec}$, respectively, which were significantly different at alpha level of 0.05 from samples with seed: water of $1: 1$ and 1:1.5. Degree of dehulling and dehulling efficiency increased with a decrease in seed: water ratio and increased shredding times. Optimal combinations of seed: water ratios with shredding time that seems to improve pigeon pea dehulling process were either seed: water at 1:1 or 1:1.5 for shredding time of $30 \mathrm{sec}$. The information from this research may be of interest to individuals who are looking for low-cost ways to improve dehulling efficiency of pigeon pea for the manufacture of flour or other uses.
\end{abstract}

Keywords: Dehulling process; Legume; Low cost; Pigeon pea

\section{Introduction}

Pigeon pea, Cajanus cajan, also known as red gram, is found throughout tropical and subtropical areas of the world, from about $30^{\circ} \mathrm{N}$ to about $30^{\circ} \mathrm{S}$ of the equator [1]. In West Africa, the mature

${ }^{\star}$ Corresponding author: Subuola B. Fasoyiro, Institute of Agricultural Research and Training PMB 5029, Moor Plantation, Ibadan, Nigeria, Tel: +234 08052281883; E-mail: subuolafasoyiro@gmail.com

Citation: Fasoyiro SB, Hovingh R, Gourama HG, Cutter CN (2020) Influence of Seed: Water Ratio and Shredding Time on Dehulling Process of Pigeon Pea. $J$ Food Sci Nutr 6: 083.

Received: November 20, 2020; Accepted: November 27, 2020; Published: December 07, 2020

Copyright: (c) 2020 Fasoyiro SB, et al. This is an open-access article distributed under the terms of the Creative Commons Attribution License, which permits unrestricted use, distribution and reproduction in any medium, provided the original author and source are credited. seeds are soaked in water, cooked, and eaten alone or with rice, yams, or a variety of vegetables. In the Caribbean, pigeon pea may be harvested green, cut, steamed, and canned or the legume may be processed into dry seeds, cooked, and canned for export [1].

In Nigeria, pigeon pea is an underutilized legume with great potential to address protein deficiency among resource-poor populations, if improvements can be made with processing and utilization technologies [2]. The underutilization of pigeon pea can be attributed to the presence of mucilage and gum, forming a strong bond between the hulls and cotyledons. The structure of the mucilage and gums present in the interface between the husk and cotyledons play an important role in the efficiency of dehulling of these legume grains [3]. Mucilage and gums of legume seeds produce a network of cellulosic micro fibrils embedded in a matrix of Non-Starch Polysaccharides (NSP) and proteins $[4,5]$, making dehulling processes difficult.

Desirable quality attributes of legumes for human consumption include dehulling efficiency and cooking quality. Generally, legumes are dehulled to improve their cooking and nutritional qualities and to remove anti-nutritional compounds, such as polyphenols located in the seed coat [6]. Pre-dehulling treatment involves loosening the husk from the cotyledons by soaking, cooking, blanching, use of chemical solutions, or a combination of processes [7]. Most dehulling processes are not only complex, but not easily adaptable for home use or for cottage industries, and therefore, are not adopted [8-10]. Therefore, this study was carried out to determine the effect of shredding time and seed: water ratio on dehulling parameters of pigeon pea, using a simple grinder adaptable for home and cottage use. The information from this study may provide individuals with an easier way to extract the hulls, allowing for more extensive use of the legume.

\section{Materials and Methods}

\section{Materials}

Pigeon pea seeds were purchased online from Barry Farm Foods (Wapakoneta, Ohio). The seeds were already cleaned and packaged in air-tight polyethylene bags. The seeds were stored at $23 \pm 2^{\circ} \mathrm{C}$ prior to use.

\section{Pre-treatment}

Pigeon pea seeds $(2 \mathrm{~kg})$ were weighed, washed, and tap water was added at ratio of 1:3 (weight/volume). The seeds were blanched for $30 \mathrm{~min}$ in boiling water, washed under running tap water, and cooled to $25-30^{\circ} \mathrm{C}$ within $5 \mathrm{~min}$.

\section{Dehulling process}

Blanched pigeon pea $(200 \mathrm{~g})$ were divided and water added to provide seed: water ratios of $2: 1,1.5: 1$, and 1:1. Resulting seed: water samples were dehulled by shredding in a blender (Model number 56250; Type B29; Hamilton Beach) for 10, 20, or $30 \mathrm{sec}$. Dehulled seeds were rinsed under running water for 3 min to removed hulls. The dehulled seeds and hulls were collected separately before calculation for yields were done. 
Citation: Fasoyiro SB, Hovingh R, Gourama HG, Cutter CN (2020) Influence of Seed: Water Ratio and Shredding Time on Dehulling Process of Pigeon Pea. J Food Sci Nutr 6: 083.

\section{Moisture content of seeds}

The initial moisture content of blanched and dehulled seeds was determined by drying $5 \mathrm{~g}$ of the seeds at $130 \pm 3^{\circ} \mathrm{C}$ for $2 \mathrm{~h}$ in a convection oven [11] and calculating moisture loss between wet and dried seeds.

\section{Dehulling data collected}

Dehulled data were collected using the method of Ikebudu et al. [12]. Briefly, $200 \mathrm{~g}$ of processed seeds at the various seed: water and processing times were separated manually into the following categories and weighed: undehulled seeds (W3), whole unbroken dehulled seeds (Wu), broken dehulled seeds (W2), tiny seed fragments (Wb), and hulls (Wh). W1 is initial weight of undehulled pigeon pea. The readings were taken four times.

\section{Calculation of dehulling parameters}

Dehulling parameters are Dehulling Index (DI), Degree of Dehulling (\%DD), Dehulling Efficiency (\%DE) and Dehulling Loss (\%DL). These calculations were done by the method of Sreerama et al. [6].

\section{Dehulling index (DI):}

$$
\mathrm{DI}=\underline{(\mathrm{W} 2+\mathrm{Wh})-(\mathrm{W} 3+\mathrm{Wb})}
$$$$
\text { W1 }
$$

Degree of dehulling (DD):

$$
\mathrm{DD} \%=\mathrm{W} 1-\mathrm{W} 3 \times 100
$$

Dehulling efficiency (DE):

$$
\underline{\mathrm{W} 1-(\mathrm{W} 3+\mathrm{Wh}+\mathrm{Wb})} \times 100
$$

Dehulling loss (DL):

$$
\underline{\mathrm{Wb}} \times 100
$$

\section{Statistical analysis}

The experimental design was $3 \times 3$ factorial ( 3 seed: water ratios $\mathrm{x}$ 3 shredding times). Statistical analyses were carried out using IBM SPSS Statistics version 23 released, 2015 (IBM Corporation, Armonk, NY). Univariate Analysis of Variance (ANOVA) was used to determine the difference between means using an alpha of 0.05 .

\section{Result and Discussion}

In this study, pigeon pea seeds at different seed: water ratio and shredding times were dehulled. Figure 1 demonstrates processing stages of dehulling pigeon pea seeds. Figure 1A demonstrates the visual observations of pigeon pea seeds before blanching, after blanching, and after cooling with water. Blanching causes the pigeon pea seeds to swell, as evidenced by the saturated seed coats, thereby allowing water to penetrate the cotyledons were observed manually. The initial moisture content of the blanched seeds was $42.5-45 \%$, while moisture contents of the dehulled seeds varied from $41.5-46.5 \%$. After blanching it was observed that the seed coats shrunk away from the cotyledons and became more transparent, allowing easy removal of the seed coats during shredding. Blanching also may lead to loss of mucilaginous substances in the seed coat, which was observed by the darkening of the blanching water. Figure 1B demonstrates dehulled pigeon seeds of different bean to water ratio and shredding times. It was observed that the degree of brokenness of seeds increased with shredding times. Sample PP1 has the least brokenness and PP9 has the highest brokenness. Hulls were better removed at shredding times of $30 \mathrm{sec}$. Dehulling increased with seed: water ratio from 2:1 to $1: 1$ to $1: 1.5$.
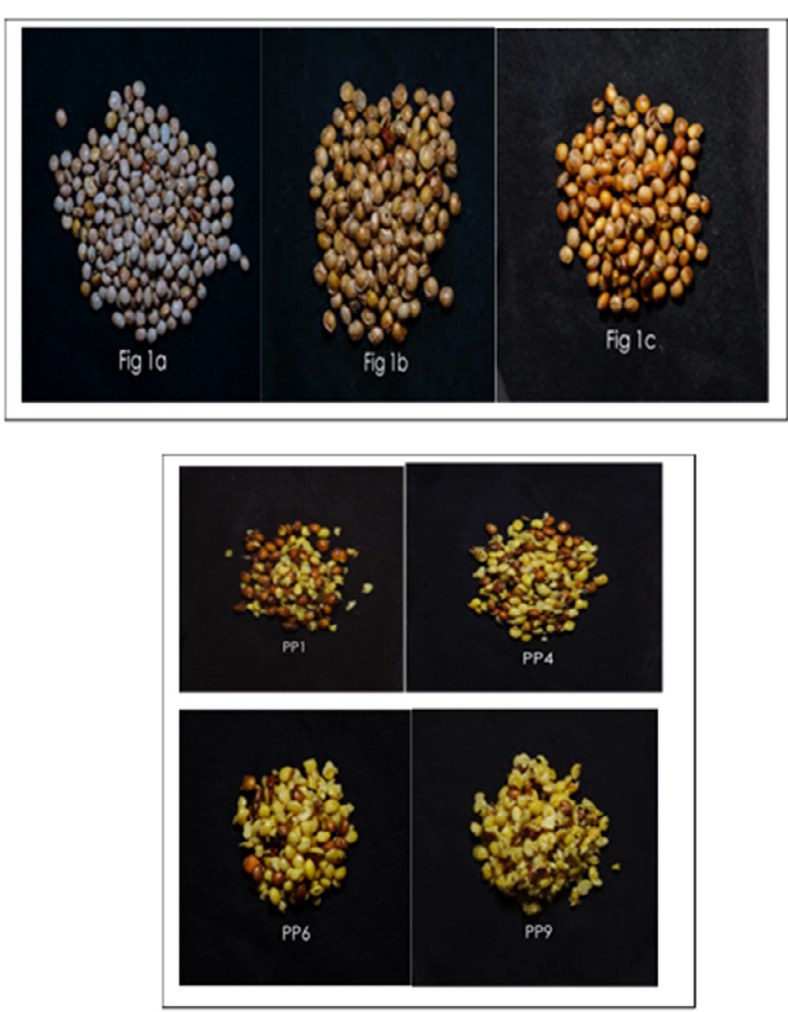

Figure 1: Processing stages of dehulling pigeon pea seeds. Figure 1A. Samples of dehulled pigeon pea seeds before blanching (Figure 1A), after blanching (Figure 1B) and after cooling (Figure 1C); Figure 1B. PP1 (seed: water ratio 2:1, shredding time $10 \mathrm{sec}$ PP4 (seed: water ratio 2:1, shredding time $10 \mathrm{sec}$ ), PP6 (seed: water ratio 1:1, shredding time $30 \mathrm{sec}$ ), PP9 (seed: water ratio 1:1.5, shredding time $30 \mathrm{sec}$ ).

Table 1 shows the yield of different fractions of pigeon pea seeds obtained from dehulling processes while figure 2 demonstrates the plot of the yields of different fractions showing trends of seed water; ratio and shredding time on yield. Undehulled pigeon pea for samples PP1, PP2 and PP3 (with seed: water 2:1) was $124.34 \mathrm{~g}, 123.13 \mathrm{~g}$ and $120.21 \mathrm{~g}$ respectively, which were significantly different at alpha 0.05 from samples at of seed: water of 1:1 and 1:1.5. Samples PP6 and PP9 (seed: water 1:1, shredding time $30 \mathrm{sec}$ and seed: water ratio 1:1.5 shredding time $30 \mathrm{sec}$ ) had preferred lowest means of undehulled seeds while PP1 (seed: water ratio 2:1, shredding time $10 \mathrm{sec}$ ) had the highest yield of undehulled seeds of $124.34 \mathrm{~g}$. Generally, it was observed that that percentage of undehulled beans decreased with decrease in seed: water and increase in shredding time. Sample PP5 (seed: water ratio $2: 1$, shredding time $20 \mathrm{sec}$ ) had the highest percentage of whole dehulled seeds of $12.37 \%$, whereas samples PP7, PP8 and PP9 (seed: water of 1:1.5), had 100\% brokenness of seeds. Broken dehulled pigeon pea seeds increased generally with shredding times for the various samples of seed: water ratio for shredding. Amount of shredded samples at 1:1 and 1:1.5 seed to water ratio doubled that which was obtained at 2:1 seed: water ratio. Broken dehulled seeds ranged from $51.99 \mathrm{~g}$ to $154.68 \mathrm{~g}$ (25.99\% to $77.34 \%)$. 
Citation: Fasoyiro SB, Hovingh R, Gourama HG, Cutter CN (2020) Influence of Seed: Water Ratio and Shredding Time on Dehulling Process of Pigeon Pea. J Food Sci Nutr 6: 083.

\begin{tabular}{|c|c|c|c|c|c|c|}
\hline Samples & Undehulled Beans (g) & Whole Dehulled Beans (g) & Broken Dehulled Beans (g) & Total Dehulled Beans (g) & Tiny fragment/Powdery (g) & Hull (g) \\
\hline PP1 & $124.34^{\mathrm{a}} \pm 12.83$ & $2.46^{\mathrm{c}} \pm 1.04$ & $51.99^{c} \pm 6.38$ & $53.69^{\mathrm{c}} \pm 3.64$ & $4.53^{\mathrm{c}} \pm 1.06$ & $7.88^{\mathrm{d}} \pm 2.44$ \\
\hline PP2 & $123.13^{\mathrm{a}} \pm 11.29$ & $4.17^{\mathrm{b}} \pm 2.44$ & $57.82^{\mathrm{c}} \pm 3.49$ & $55.93^{\mathrm{c}} \pm 4.33$ & $4.42^{\mathrm{c}} \pm 1.97$ & $9.39^{\mathrm{d}} \pm 2.68$ \\
\hline PP3 & $120.21^{\mathrm{a}} \pm 5.10$ & $1.31^{\mathrm{c}} \pm 0.98$ & $62.35^{\mathrm{c}} \pm 4.02$ & $60.49^{\mathrm{c}} \pm 1.01$ & $9.85^{\mathrm{a}} \pm 1.78$ & $19.51^{\mathrm{c}} \pm 4.25$ \\
\hline PP4 & $58.59^{\mathrm{b}} \pm 6.84$ & $2.42^{\mathrm{c}} \pm 1.46$ & $117.20^{\mathrm{b}} \pm 16.32$ & $111.19^{\mathrm{b}} \pm 11.6$ & $6.12^{\mathrm{ab}} \pm 1.35$ & $22.60^{\mathrm{bc}} \pm 1.76$ \\
\hline PP5 & $29.42^{\mathrm{c}} \pm 4.03$ & $12.37^{a} \pm 2.48$ & $123.07^{b} \pm 7.19$ & $128.91^{\mathrm{b}} \pm 11.28$ & $3.38^{\mathrm{c}} \pm 1.61$ & $21.54^{\mathrm{b}} \pm 3.17$ \\
\hline PP6 & $3.64^{\mathrm{e}} \pm 1.77$ & $6.63^{b} \pm 1.98$ & $146.25^{a} \pm 4.79$ & $154.27^{\mathrm{a}} \pm 6.07$ & $4.84^{b} \pm 1.26$ & $28.55^{\mathrm{a}} \pm 2.88$ \\
\hline PP7 & $40.89^{c} \pm 5.46$ & - & $122.29^{b} \pm 13.34$ & $118.74^{b} \pm 10.61$ & $8.06^{\mathrm{ab}} \pm 3.74$ & $26.30^{a \mathrm{ab}} \pm 4.69$ \\
\hline \multicolumn{7}{|l|}{ PP8 } \\
\hline \multirow[t]{2}{*}{ PP9 } & $23.68^{\mathrm{cd}} \pm 4.14$ & - & $139.72^{\mathrm{ab}} \pm 3.55$ & $139.72^{\mathrm{ab}} \pm 3.07$ & $7.62^{\mathrm{ab}} \pm 2.76$ & $21.41^{\mathrm{ab}} \pm 3.73$ \\
\hline & $4.14^{\mathrm{e}} \pm 1.62$ & - & $154.68^{\mathrm{a}} \pm 8.81$ & $154.68^{\mathrm{a}} \pm 7.37$ & $8.17^{\mathrm{ab}} \pm 1.81$ & $30.74^{\mathrm{a}} \pm 3.92$ \\
\hline
\end{tabular}

Table 1: Yield of different fractions of pigeon pea seeds obtained from dehulling processes.

Note: Means in the same column not followed by the same superscript are significantly different at an of alpha 0.05 . Yield (g) of different fractions of pigeon pea samples and standard deviations are mean of $(n=4$; number of dehulled pigeon pea samples). Key; PP1- seed: water ratio 2:1, shredding time 10 sec, seed: water ratio 2:1, shredding time 10 sec, PP2- seed: water ratio 2:1, shredding time $20 \mathrm{sec}$, PP3- seed: water ratio 2:1, shredding time 30 sec, PP4- seed: water ratio 1:1, shredding time 10 sec, PP5- seed: water ratio 1:1, shredding time $20 \mathrm{sec}$, PP6- seed: water ratio 1:1, shredding time $30 \mathrm{sec}$, PP7 seed: water ratio 1:1.5, shredding time 10 sec, PP8- seed: water ratio 1:1.5, shredding time 20 sec, PP9- seed: water rato1;1.5, shredding time $30 \mathrm{sec}$.

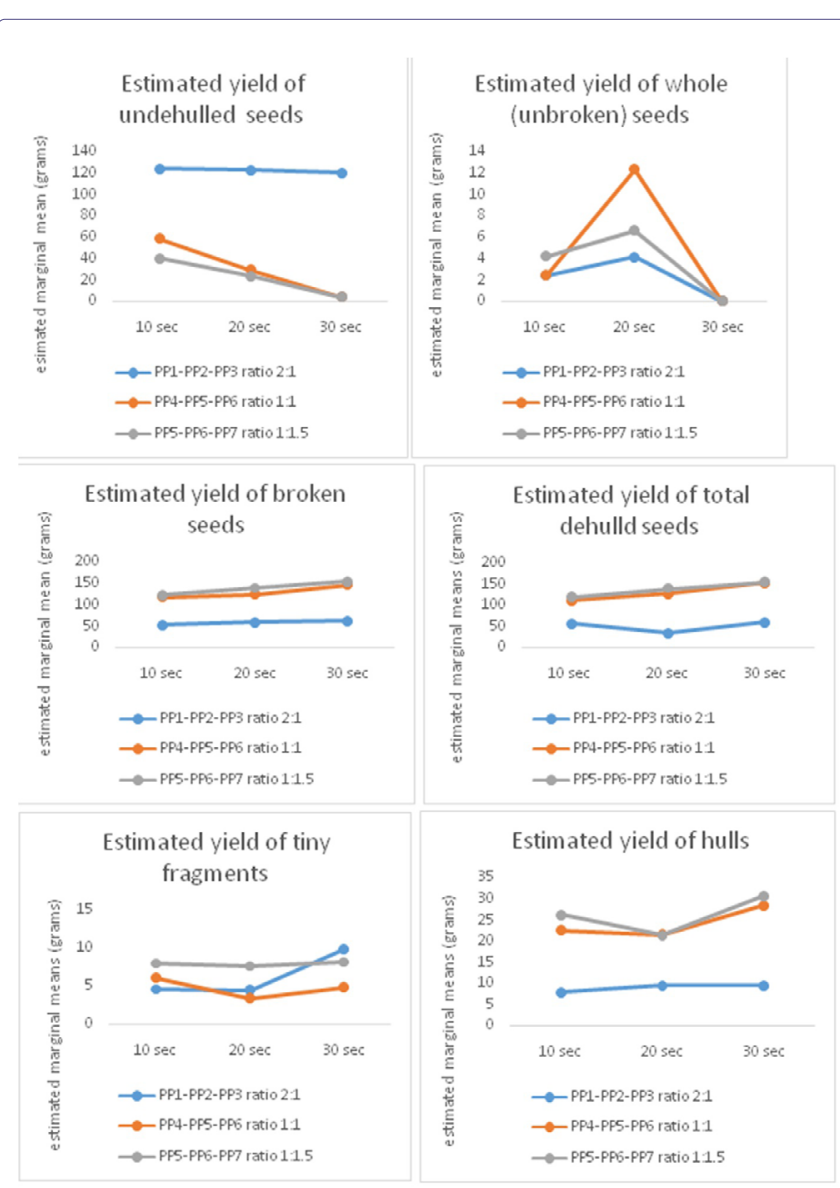

Figure 2: Plots of yield of different fractions of dehulled pigeon pea seeds.

Note: Yield ( $\mathrm{g}$ ) of different fractions of pigeon pea samples and standard deviations are mean of ( $\mathrm{n}=4$; number of dehulled pigeon pea samples). Key; PP1- seed: water ratio 2:1, shredding time $10 \mathrm{sec}$, seed: water ratio 2:1, shredding time $10 \mathrm{sec}$, PP2- seed: water ratio 2:1, shredding time $20 \mathrm{sec}$, PP3- seed: water ratio 2:1, shredding time 30 sec, PP4- seed: water ratio $1: 1$, shredding time $10 \mathrm{sec}$, PP5- seed: water ratio $1: 1$, shredding time $20 \mathrm{sec}$, PP6- seed: water ratio 1:1, shredding time $30 \mathrm{sec}$, PP7 seed: water ratio $1: 1.5$, shredding time $10 \mathrm{sec}, \mathrm{PP} 8$ - seed: water ratio $1: 1.5$, shredding time $20 \mathrm{sec}$, PP9- seed: water rato1;1.5, shredding time $30 \mathrm{sec}$.
Total yield of dehulled seeds (whole plus broken) ranged from $53.69 \mathrm{~g}$ to $154.68 \mathrm{~g}$. Highest deshelled yields were obtained from sample PP9 (seed: water ratio 1:1.5, shredding time $30 \mathrm{sec}$ ) with seed recovery of $154.68 \mathrm{~g}(77.34 \%)$ and total brokenness of seeds $(100 \%)$; which was not significantly different at alpha 0.05 from PP6 (seed: water ratio $2: 1$, shredding time $30 \mathrm{sec}$ ) with total seed recovery of $154.27 \mathrm{~g}(77.12 \%)$. Singh (1995) reported a maximum theory recovery of dehulled beans of $87-89 \%$ for improved dehulling processes while traditional processes had a total recovery of $65-75 \%$. The maximum yield obtained in this study was lower than the maximum yield recovery reported from previous processes but higher that what was obtainable from traditional processes reported. The lowest average tiny fragment of the seed was from PP5 (seed: water ratio 1:1, shredding time $20 \mathrm{sec}$ ). Samples of seed: water ratio 2:1 had the lowest yield of hulls indicating more of undehulled seeds while those of seed: water ratio 1:1 and 1:1.1.5 were higher and at a closer range.

Dehulling index is usually a value of maximum of 1 relating broken seeds, whole unbroken with hulls and lost fragment in connection to amount of seeds dehulled. Dehulling Index (Figure 3) generally increased with shredding time and seed to water ratio. The dehulling index for samples PP1, PP2 and PP3 (seed: water ratio 1:1) were negative for the different shredding time. Sample of seed: water ratio 1:1.5 had highest level of dehulling index compared to samples of seed: water ratios 2:1 and 1:1 with shredding times. Sample PP9 (seed: water ratio $1: 1.5$, shredding time $30 \mathrm{sec}$ ) had the highest dehulling index of 0.87 while the lowest was for sample PP1 (seed: water ratio $1: 1$, shredding time $10 \mathrm{sec}$ ) at -0.35 . Sreerama et al. [6], obtained a higher dehulling index of 0.93 for xylanse-treated horse gram.

Figures 4 and 5 demonstrate the Degree of Dehulling (\%DD) and Dehulling Efficiency $(\% \mathrm{DE})$ of the pigeon pea samples. The degree of dehulling or hull removal is the percentage of dehulled beans to the initial weight of sample taken for dehulling. Dehulling efficiency is an estimate of the efficiency of producing the major product, dehulled seeds. The \%DD and \%DE increased with seed: water and shredding time. Generally, samples of seed: water ratios 1:1.5 had the highest $\% \mathrm{DD}$ with shredding times compared to samples of seed: water ratios $2: 1$ and $1: 1$, with shredding times, but there was not much difference between PP6 (seed: water ratio 1:1, shredding time 30 sec), PP8 (seed: 


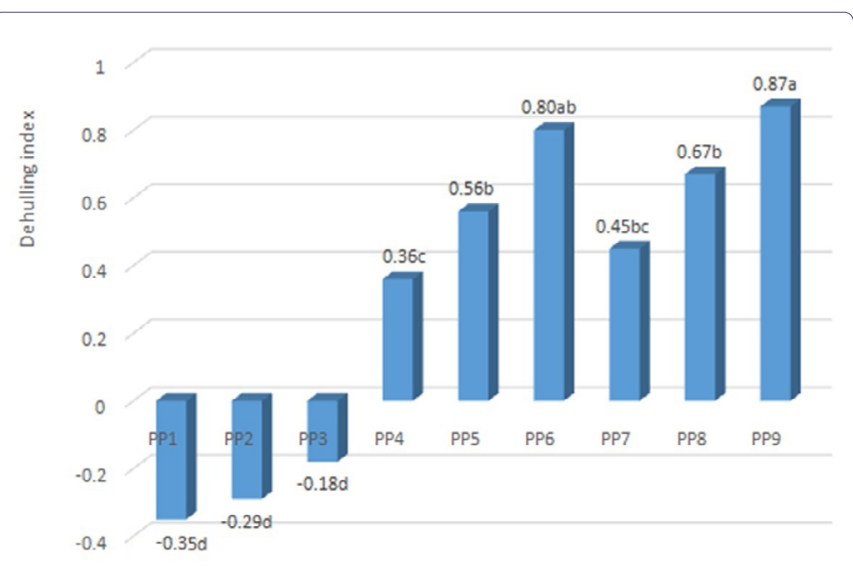

Figure 3: Dehulling index of pigeon pea samples (DI).

Note: Different letters represent significant difference of dehulling index of pigeon pea samples at an alpha of 0.05 . Key; PP1- seed: water ratio 2:1, shredding time 10 sec, seed: water ratio $2: 1$, shredding time $10 \mathrm{sec}$, PP2- seed: water ratio 2:1, shredding time 20 sec, PP3- seed: water ratio 2:1, shredding time $30 \mathrm{sec}$, PP4- seed: water ratio $1: 1$, shredding time $10 \mathrm{sec}$, PP5- seed: water ratio 1:1, shredding time $20 \mathrm{sec}$, PP6seed: water ratio $1: 1$, shredding time $30 \mathrm{sec}$, PP7 seed: water ratio $1: 1.5$, shredding time $10 \mathrm{sec}$, PP8- seed: water ratio 1:1.5, shredding time $20 \mathrm{sec}$, PP9- seed: water rato $1 ; 1.5$, shredding time $30 \mathrm{sec}$.

water ratio $1: 1.5$, shredding time $20 \mathrm{sec}$ and PP8 (seed: water ratio $1: 1.5$, shredding $30 \mathrm{sec}$ ). Both the samples of seed: water ratios 1:1.5 and 1.1 shredded for $30 \mathrm{sec}$ (PP6 and PP9) had the highest Dehulling Efficiency (\%DE) at $79.9 \%$ and 79.8 respectively. Lowest degree of dehulling was recorded for PP1 (seed: water ratio 1:1, shredding time $10 \mathrm{sec}$ ) at $33.3 \%$ and lowest dehulling efficiency for PP3 (seed: water ratio $1: 1$, shredding time $30 \mathrm{sec}$ ) at $27.2 \%$. Sreerama et al. [6], also reported highest degree of dehulling of $98.4 \%$ for xylanase-treated horse gram. Goyal et al. [13], also reported increased dehulling efficiency with dehulling time with optimal dehulling efficiency of $83.2 \%$ obtained for pigeon pea pre-treated with $0.3 \%$ mustard oil.

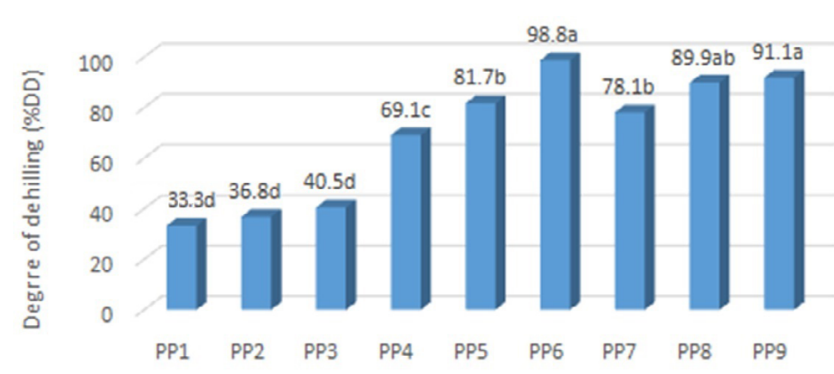

Figure 4: Percentage degree of dehulling of pigeon pea samples.

Note: Different letters represent significant difference of dehulling index of pigeon pea Different letters represent significant difference of degree of dehulling of pigeon pea samples at an alpha of 0.05 . Key; PP1- seed: water ratio 2:1, shredding time 10 sec, seed: water ratio $2: 1$, shredding time $10 \mathrm{sec}$, PP2- seed: water ratio $2: 1$, shredding time $20 \mathrm{sec}$, PP3- seed: water ratio 2:1, shredding time $30 \mathrm{sec}$, PP4- seed: water ratio 1:1, shredding time $10 \mathrm{sec}$, PP5- seed: water ratio 1:1, shredding time $20 \mathrm{sec}$, PP6seed: water ratio $1: 1$, shredding time $30 \mathrm{sec}$, PP7 seed: water ratio $1: 1.5$, shredding time $10 \mathrm{sec}$, PP8- seed: water ratio $1: 1.5$, shredding time 20 sec, PP9- seed: water rato $1 ; 1.5$, shredding time $30 \mathrm{sec}$.

Figure 6 demonstrates the dehulling loss of the seeds. Dehulling loss is the percentage of broken seeds in powdery form. Dehulling Loss (\%DL) was in the range of 2.26 to $4.82 \%$, which was independent of either seed: water or the shredding time. Singh et al. [14], reported 5.5 to $6.1 \%$ dehulling loss for pigeon pea and 9 to $24.6 \%$

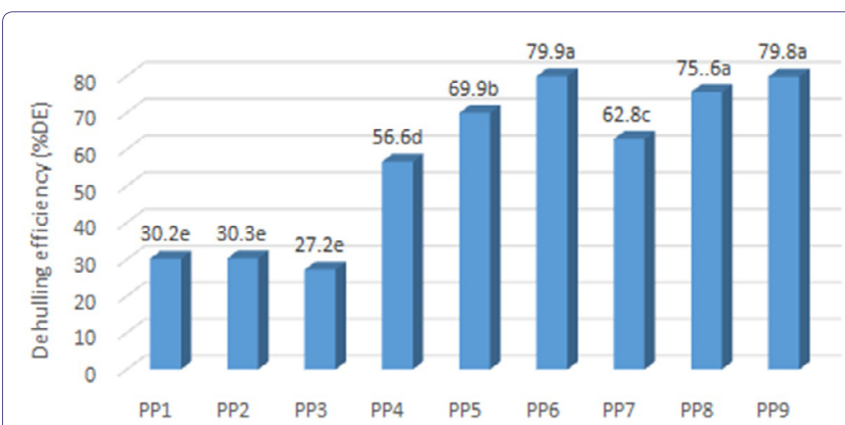

Figure 5: Percentage dehulling efficency of pigeon pea samples.

Note: Different letters represent significant difference of dehulling efficiency of pigeon pea samples at an alpha of 0.05 . Key; PP1- seed: water ratio 2:1, shredding time $10 \mathrm{sec}$, seed: water ratio $2: 1$, shredding time $10 \mathrm{sec}$, PP2- seed: water ratio $2: 1$, shredding time $20 \mathrm{sec}$, PP3- seed: water ratio $2: 1$, shredding time $30 \mathrm{sec}$, PP4- seed: water ratio 1:1, shredding time $10 \mathrm{sec}, \mathrm{PP} 5$ - seed: water ratio 1:1, shredding time 20 sec, PP6- seed: water ratio 1:1, shredding time $30 \mathrm{sec}$, PP7 seed: water ratio 1:1.5, shredding time $10 \mathrm{sec}$, PP8- seed: water ratio 1:1.5, shredding time $20 \mathrm{sec}$, PP9- seed: water rato1;1.5, shredding time $30 \mathrm{sec}$.

broken seed. Sample PP3 (seed: water of 2:1 and shredding time of $30 \mathrm{sec}$ ) had the highest dehulling loss, while PP6 (seed: water of 1:1 and shredding time of $30 \mathrm{sec}$ ) had the lowest followed by PP8 (seed: water ratio 1:1.5, shredding time $20 \mathrm{sec}$ ). Singh et al. [14] and Singh et al. [15], reported a dehulling loss of 4.4 to $12.8 \%$ in some studies, while Sreerama et al. [6], reported a dehulling loss of $3.1 \%$ which was observed to reduce with increasing moisture content levels in pulses. In a centrifugal process reported by Gupta and Das [16], for dehulling of sunflower, dehulling efficiency decreased with increased moisture content and feed rate.

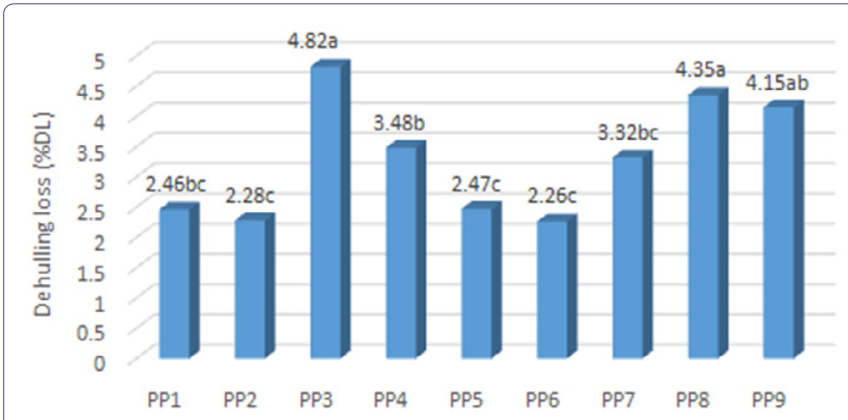

Figure 6: Percentage dehulling loss of pigeon pea samples.

Note: Different letters represent significant difference of dehulling loss of pigeon pea samples at an alpha of 0.05 . Key; PP1- seed: water ratio 2:1, shredding time $10 \mathrm{sec}$, seed: water ratio $2: 1$, shredding time $10 \mathrm{sec}$, PP2- seed: water ratio $2: 1$, shredding time $20 \mathrm{sec}$, PP3- seed: water ratio 2:1, shredding time $30 \mathrm{sec}$, PP4- seed: water ratio $1: 1$, shredding time $10 \mathrm{sec}$, PP5- seed: water ratio 1:1, shredding time $20 \mathrm{sec}$, PP6seed: water ratio $1: 1$, shredding time $30 \mathrm{sec}$, PP7 seed: water ratio $1: 1.5$, shredding time $10 \mathrm{sec}$, PP8- seed: water ratio 1:1.5, shredding time $20 \mathrm{sec}$, PP9- seed: water rato $1 ; 1.5$, shredding time $30 \mathrm{sec}$.

\section{Conclusion}

This study demonstrates optimal combinations of seed: water ratios with shredding time that seems to improve pigeon pea dehulling process as either seed: water ratios at 1:1 or 1:1.5 for shredding time of $30 \mathrm{sec}$. This dehulling process will not be applicable to food where whole seeds are desirable. The process will, however, find useful application to products where broken or split beans are acceptable in semi-finished products, such as in legume flour, bean porridges, bean puddings, or as a thickener. These results indicate that improved dehulling properties for pigeon pea seeds have the potential for 
Citation: Fasoyiro SB, Hovingh R, Gourama HG, Cutter CN (2020) Influence of Seed: Water Ratio and Shredding Time on Dehulling Process of Pigeon Pea. J Food Sci Nutr 6: 083.

better utilization and adoption, especially in households and cottage use where low cost technologies are required.

\section{Conflict of Interest}

The authors acknowledge that there is no conflict of interest.

\section{Acknowledgement}

The authors would like to acknowledge Pennsylvania State University Library Data Learning Centre for the statistical analysis and interpretation. This research did not receive any specific grant from funding agencies in the public, commercial, or not-for-profit sectors.

\section{References}

1. Duke JA (1981) Handbook of Legumes of World Economic Importance. Plenum Press, New York, USA.

2. Nwokolo E (1996) Food and feed from legumes and oilseeds. Publisher Chapman hall, London, UK.

3. Ramakrishnaiah N, Kurien PP (1983) Variability in the dehulling characteristics of pigeon pea (Cajanus cajan L.) cultivars. Journal of Food Science and Technology 20: 287-291.

4. Cosgrove DJ (1997) Assembly and enlargement of the primary cell wall in plants. Annu Rev Cell Dev Biol 13: 171-201.

5. Phirke PS, Bhole NG (2000) Pretreatment of pigeon pea grain for improvement of dehulling characteristics. International Journal of Food Science and Technology 35: 305-313.

6. Sreerama YN, Sashikala VB, Pratape VM (2009) Effect of enzyme pre-dehulling treatments on dehulling and cooking properties. Journal of Food Engineering 92: 389-395.
7. Phirke PS, Bhole NG (1999) The effect of pretreatment on the strength and dehulling properties of pigeon pea grain. International Journal of Food Science and Technology 34: 107-113.

8. Singh D, Sokhananj S (1984) Cylindrical concave mechanism and chemical treatment for dehulling of pigeon pea. Agricultural Mechanization in Asia, Africa and Latin America 15: 53-58.

9. Reichert RD, Ooman BD, Youngs CG (1984) Factors affecting the efficiency of abrasive type dehulling of grain legumes investigated with a new intermediate size batch dehuller. Food Science 49: 267-272.

10. Phirke PS, Pumbarka S, Taore AB (1992) Evaluation of chemical pretreatment of pigeon pea grains for milling. Indian Journal of Agricultural Engineering 2: 141-142.

11. AOAC (2012) Official Methods of Analysis of the Association of Official Analytical Chemists. (19 th $\left.^{\text {th }}\right)$. AOAC International, Maryland, USA.

12. Ikebudu JA, Sokhansanj S, Tyler RT, Milne BJ, Thakor NS (2000) Grain conditioning for dehulling of canola. Canadian Agricultural Engineering 42: $27-32$.

13. Goyal RK, Vishwakarma RK, Wanjari OD (2008) Optimization of pigeon pea dehulling process. Biosystems Engineering 99: 56-61.

14. Singh U, Santosa BAS, Rao PV (1992) Effect of dehulling methods and physical characteristics of grains on dhal yield of pigeon pea (Cajanus cajan L.) gentotypes. Journal of Food Science and Technology 29: 350353.

15. Singh U (1995) Methods of dehulling of pulses. A critical appraisal. Journal of Food Science and Technology 32: 81-93.

16. Gupta RK, Das SK (1999) Performance of centrifugal dehulling system for sunflower. Journal of Food Engineering 42: 191-198. 


\section{$\mathbb{d}$ \\ Hнram}

Advances In Industrial Biotechnology | ISSN: 2639-5665

Advances In Microbiology Research | ISSN: 2689-694X

Archives Of Surgery And Surgical Education | ISSN: 2689-3126

Archives Of Urology

Archives Of Zoological Studies | ISSN: 2640-7779

Current Trends Medical And Biological Engineering

International Journal Of Case Reports And Therapeutic Studies | ISSN: 2689-310X

Journal Of Addiction \& Addictive Disorders | ISSN: 2578-7276

Journal Of Agronomy \& Agricultural Science | ISSN: 2689-8292

Journal Of AIDS Clinical Research \& STDs | ISSN: 2572-7370

Journal Of Alcoholism Drug Abuse \& Substance Dependence | ISSN: 2572-9594

Journal Of Allergy Disorders \& Therapy | ISSN: 2470-749X

Journal Of Alternative Complementary \& Integrative Medicine | ISSN: 2470-7562

Journal Of Alzheimers \& Neurodegenerative Diseases | ISSN: 2572-9608

Journal Of Anesthesia \& Clinical Care | ISSN: 2378-8879

Journal Of Angiology \& Vascular Surgery | ISSN: 2572-7397

Journal Of Animal Research \& Veterinary Science | ISSN: 2639-3751

Journal Of Aquaculture \& Fisheries | ISSN: 2576-5523

Journal Of Atmospheric \& Earth Sciences | ISSN: 2689-8780

Journal Of Biotech Research \& Biochemistry

Journal Of Brain \& Neuroscience Research

Journal Of Cancer Biology \& Treatment | ISSN: 2470-7546

Journal Of Cardiology Study \& Research | ISSN: 2640-768X

Journal Of Cell Biology \& Cell Metabolism | ISSN: 2381-1943

Journal Of Clinical Dermatology \& Therapy | ISSN: 2378-8771

Journal Of Clinical Immunology \& Immunotherapy | ISSN: 2378-8844

Journal Of Clinical Studies \& Medical Case Reports | ISSN: 2378-8801

Journal Of Community Medicine \& Public Health Care | ISSN: 2381-1978

Journal Of Cytology \& Tissue Biology | ISSN: 2378-9107

Journal Of Dairy Research \& Technology | ISSN: 2688-9315

Journal Of Dentistry Oral Health \& Cosmesis | ISSN: 2473-6783

Journal Of Diabetes \& Metabolic Disorders | ISSN: 2381-201X

Journal Of Emergency Medicine Trauma \& Surgical Care | ISSN: 2378-8798

Journal Of Environmental Science Current Research | ISSN: 2643-5020

Journal Of Food Science \& Nutrition | ISSN: 2470-1076

Journal Of Forensic Legal \& Investigative Sciences | ISSN: 2473-733X

Journal Of Gastroenterology \& Hepatology Research | ISSN: 2574-2566
Journal Of Genetics \& Genomic Sciences | ISSN: 2574-2485

Journal Of Gerontology \& Geriatric Medicine | ISSN: 2381-8662

Journal Of Hematology Blood Transfusion \& Disorders | ISSN: 2572-2999

Journal Of Hospice \& Palliative Medical Care

Journal Of Human Endocrinology | ISSN: 2572-9640

Journal Of Infectious \& Non Infectious Diseases | ISSN: 2381-8654

Journal Of Internal Medicine \& Primary Healthcare | ISSN: 2574-2493

Journal Of Light \& Laser Current Trends

Journal Of Medicine Study \& Research | ISSN: 2639-5657

Journal Of Modern Chemical Sciences

Journal Of Nanotechnology Nanomedicine \& Nanobiotechnology | ISSN: 2381-2044 Journal Of Neonatology \& Clinical Pediatrics | ISSN: 2378-878X

Journal Of Nephrology \& Renal Therapy | ISSN: 2473-7313

Journal Of Non Invasive Vascular Investigation | ISSN: 2572-7400

Journal Of Nuclear Medicine Radiology \& Radiation Therapy | ISSN: 2572-7419

Journal Of Obesity \& Weight Loss | ISSN: 2473-7372

Journal Of Ophthalmology \& Clinical Research | ISSN: 2378-8887

Journal Of Orthopedic Research \& Physiotherapy | ISSN: 2381-2052

Journal Of Otolaryngology Head \& Neck Surgery | ISSN: 2573-010X

Journal Of Pathology Clinical \& Medical Research

Journal Of Pharmacology Pharmaceutics \& Pharmacovigilance | ISSN: 2639-5649

Journal Of Physical Medicine Rehabilitation \& Disabilities | ISSN: 2381-8670

Journal Of Plant Science Current Research | ISSN: 2639-3743

Journal Of Practical \& Professional Nursing | ISSN: 2639-5681

Journal Of Protein Research \& Bioinformatics

Journal Of Psychiatry Depression \& Anxiety | ISSN: 2573-0150

Journal Of Pulmonary Medicine \& Respiratory Research | ISSN: 2573-0177

Journal Of Reproductive Medicine Gynaecology \& Obstetrics | ISSN: 2574-2574

Journal Of Stem Cells Research Development \& Therapy | ISSN: 2381-2060

Journal Of Surgery Current Trends \& Innovations | ISSN: 2578-7284

Journal Of Toxicology Current Research | ISSN: 2639-3735

Journal Of Translational Science And Research

Journal Of Vaccines Research \& Vaccination | ISSN: 2573-0193

Journal Of Virology \& Antivirals

Sports Medicine And Injury Care Journal | ISSN: 2689-8829

Trends In Anatomy \& Physiology | ISSN: 2640-7752

Submit Your Manuscript: https://www.heraldopenaccess.us/submit-manuscript 